MICHAE MARCINIAK

Uniwersytet im. Adama Mickiewicza

w Poznaniu

\title{
WYCHOWANIE FIZYCZNE \\ NA UNIWERSYTECIE NOTRE DAME \\ W SOUTH BEND INDIANA \\ - TRADYCJA, PROCES, NAUCZYCIELE
}

\begin{abstract}
Marciniak Michał, Wychowanie fizyczne na Uniwersytecie Notre Dame w South Bend Indiana tradycja, proces, nauczyciele [Physical Education at Notre Dame University in South Bend Indiana Tradition, Process, Teachers]. Studia Edukacyjne nr 43, 2017, Poznań 2017, pp. 263-281. Adam Mickiewicz University Press. ISSN 1233-6688. DOI: 10.14746/se.2017.43.16

The author of this article presensts the structure of physical education and sports at the academic level at Notre Dame University in South Bend Indiana. The first part describes the historical aspect, the most important dates, names of the university. The next part is an analysis of the program of physical education classes, sports facilities and budget for sport. In the last part, the author attempted to present a episode of his qualitative research at Notre Dame University during his stay in 20122014. The research concerned the professional satisfaction of physical education teachers at the University of Notre Dame.
\end{abstract}

Key words: Notre Dame University, physical education classes, physical education teachers, Athletics Department

Nikt nie zaprzeczy, że w trakcie rozwoju młodego człowieka powinna istnieć korelacja pomiędzy orientacją na rozwój umysłowy i osobowościowy, a z drugiej strony na utrzymanie i rozwój jego sprawności fizycznej, co bez wątpienia służy zdrowiu. Nie ulega też wątpliwości, że te sfery powinny się przenikać i wzajemnie wzmacniać. Niestety, na wszystkich szczeblach edukacji rozwój fizyczny dzieci i młodzieży jest często zaniedbywany, postrzegany jako nieważny, a niekiedy nawet wręcz odrzucany. Dotyczy to również szkolnictwa wyższego. 
Celem mojego artykułu jest przedstawienie wybranych kontekstów z wychowania fizycznego na Uniwersytecie Notre Dame w South Bend Indiana w Stanach Zjednoczonych. Instytucja ta stanowi znakomitą egzemplifikację najlepszych tradycji i najwyższej jakości amerykańskiego szkolnictwa wyższego.

Uniwersytet Notre Dame w roku 2017 znajduje się na 203 miejscu uniwersytetów na świecie w słynnym QS World University Rankings ${ }^{1}$. Z kolei, $\mathrm{w}$ innym światowym rankingu World University Rankings plasuje się na 143 miejscu $^{2}$. W Academic Ranking of Universities z 2016 roku zajmował miejsce 201, razem $\mathrm{z}$ wieloma innymi uniwersytetami ${ }^{3}$. Jeśli chodzi o Stany Zjednoczone, w najbardziej prestiżowym amerykańskim rankingu US News and World Report na rok 2017 uzyskał miejsce 15, wspólnie z dwoma innymi uniwersytetami Cornell University i Rice University 4 .

Uniwersytet Notre Dame jest prywatną katolicką uczelnią wyższą położoną w stanie Indiana, w miejscowości South Bend, $90 \mathrm{~km}$ na wschód od Chicago. Został utworzony 26 listopada 1842 roku przez francuskiego Ojca Edwarda Sorina, Francuza, członka Zakonu Świętego Krzyża. W związku $\mathrm{z}$ rosnącym w Stanach Zjednoczonych zapotrzebowaniem na misjonarzy, Ojciec Sorin został wybrany przez swoich przełożonych i wraz z sześcioma braćmi zakonnymi wyjechał do Ameryki ${ }^{5}$. Uniwersytet został oficjalnie utworzony 15 stycznia 1844 roku, na mocy specjalnej ustawy zatwierdzonej przez władze wykonawcze stanu Indiana (tzw. Zgromadzenie Stanu Indiana - ang. Indiana General Assembly). Warto wspomnieć, że niebagatelną zasługę miał w tym względzie stanowy senator John B. De Frees ${ }^{6}$.

W marcu 1843 roku istniały już trzydzieści cztery budynki kampusu, między innymi kaplice (Log Chanel, Badin Chanel, Log Chanel Interior). $\mathrm{Z}$ roku na rok kampus uniwersytetu Notre Dame rozwijał się i przyciągał młodzież. W roku 1853 w powstałym budynku Mini Departament uczono

1 Por. QS World University Rankings, adres internetowy: https://www.topuniv ersities.com/university-rankings/world-university-rankings/2016.

2 Por. World University Rankings, adres internetowy: https://www.timeshigher education.com/world-university-rankings/2017/world-

ranking\#!/page/0/length/25/sort_by/rank/sort_order/asc/cols/stats.

3 Por. Academic Ranking of World Universities, adres internetowy: http://www. shanghairanking.com/ARWU2016.html.

${ }_{4}^{4}$ Por. US News and World Report, adres internetowy: https://www.usnews.com/bestcolleges/rankings/national-universities.

${ }^{5}$ M.A. Sperber, Shake Down the Thunder, The Creation of Notre Dame Football, Indiana University Press, South Bend Indiana, 1993, s. 9.

6 J.T. Wack, The Story of Notre Dame. The University of Notre Dame du Lac, Foundations, 1842-1857, Notre Dame South Bend Indiana, adres internetowy: http://archives.nd. edu/wack/wack01.htm 
młodych chłopców podstaw czytania, pisania, arytmetyki, gramatyki i historii. W budynku Junior Departament uczono młodzież greki i angielskiego, w budynku Senior Departament prowadzono zajęcia z języka francuskiego, hiszpańskiego oraz historii świata. Do uniwersytetu przyjmowano praktycznie każdego, jeśli kogoś nie było stać na zapłacenie czesnego, w zamian za naukę wykonywał różne prace pomocnicze dla kampusu. Uniwersytet dzięki wytrwałości Ojca Sorina wciąż dynamicznie się rozbudowywał7.

W 1851 roku do South Bend doprowadzono linię kolejową, założono w Notre Dame pocztę i dobudowano dwa skrzydła do budynku głównego Uczelni. Okres gwałtownego rozkwitu na Uczelni trwał do 1853 roku$^{8}$. W tymże roku epidemia cholery nawiedzając Stany Zjednoczone dotarła rok później do Notre Dame. Pochłonęła wiele ofiar, a college został przekształcony w Główny Szpital i wymagał generalnego remontu w obliczu zwiększającej się liczby chorych? .

Ojciec Edward Sorin był prezydentem (z polskiej perspektywy - rektorem) Uniwersytetu do roku 1865. W tym okresie istniało 9 innych katolickich college'ów na terenie całego kraju, ale już wtedy Uniwersytet Notre Dame zaliczany był do czołówki. W latach 1861-1873 utworzono wydziały: ekonomiczny (1861), nauk przyrodniczych (1865), prawa (1869) oraz inżynierii (1873). W 1865 roku powstało wydawnictwo uniwersyteckie, tygodnik religijny "The Ave Maria" oraz czasopismo miesięczne "The Scholastic". Od roku 1868 istniało Stowarzyszenie Absolwentów. W roku 1865 nowym rektorem uczelni został Ojciec Patrik Dilon, zaś Ojciec Edward Sorin - generałem Zakonu Świętego Krzyża, ale cały czas miał duży wpływ na rozwój uniwersytetu i przeprowadzane w nim zmiany. W latach 1872-1874 rektorem został prawnik i siostrzeniec Sorina - Ojciec August Lemonnier. Przyczynił się on do rozbudowy biblioteki uniwersyteckiej oraz rozwoju aparatury naukowej. Utworzono również Muzeum Uniwersyteckie zawierające pamiątki oraz różnego rodzaju przedmioty po wojnie secesyjnej ${ }^{10}$.

Kiedy w latach 1861-1865 w Stanach Zjednoczonych wybuchła wojna secesyjna (ang. Civil War), Uniwersytet Notre Dame mimo to cały czas rozbudowywał się. Jedną $\mathrm{z}$ największych inwestycji w tym czasie było wybudowanie w roku 1863 Budynku Głównego II (ang. Main Building II). Ponadto, zarówno podczas wojny secesyjnej, jak i I i II wojny światowej uniwersytet stanowił bazę treningową dla armii. Wiosną 1869 roku szefem Rady Nad-

7 T.J. Schlereth, The University of Notre Dame. A Portrait of Its History and Campus, South Bend Indiana 1977, s. I-18, I-26.

8 J.W. Cavanaugh, Notes on Early History of Notre Dame, South Bend Indiana 1954, s. 121.

${ }_{9}$ Tamże, s. 122.

10 T.J. Schlereth, The University of Notre Dame, s. 37. 
zorczej Uniwersytetu, która brała udział w tworzeniu statutu uniwersytetu oraz w wyborze nowych urzędników i członków uniwersytetu (ang. The University Board of Trustees), został Edward Sorin. Podejmował wraz z członkami rady najważniejsze decyzje dotyczące Uczelni, dysponował budżetem Uniwersytetu. Sorin podjął między innymi decyzje o budowie kościoła Secred Hart w 1871 roku. Był on kilkakrotnie remontowany i w końcu stał się bazyliką. W latach 1881-1893 rektorem został Thomas Walsh. Stworzył on specjalny regulamin studencki na uniwersytecie (ang. University Regulations), składający się z 25 punktów, których studenci mieli obowiązek przestrzegać. Nakazywał on studentom między innymi odpowiednio się zachowywać, nie spóźniać na zajęcia, prowadzić dzienniki zajęć, zachowywać spokój i porządek, pokrywać koszty za wszelkie zniszczenia mienia uczelni. Student nie mógł opuścić zajęć bez zgody prowadzącego, do którego musiał odnosić się z szacunkiem. Regulaminem tym kierowały się władze uczelni ${ }^{11}$.

W roku 1888 Uniwersytet Notre Dame po raz pierwszy wziął udział w katolickich międzyuniwersyteckich zawodach sportowych. Na Uczelni istniała wówczas już dość znacznie rozbudowana baza sportowa. Basen znajdował się w budynku Rockne Memorial Building. Funkcjonowała także sala gimnastyczna, połączona ze sprzętem siłowym, którą założył ówczesny najsilniejszy człowiek Ameryki - Ojciec Lang. Od jego nazwiska nazwano to miejsce "Siłownią Ojca Langa" (ang. Father's Lange Gym). Ponadto, istniało kilka boisk do rugby, tor wyścigowy dla rowerów, boisko do gry w lacrosse, czy lodowiska na zamarzniętych zimą jeziorach, a w Rockefeller Hall odbywały się mecze koszykówki. Na rozgrywki w football amerykański ludność z całej okolicy, jak również z Chicago transportowana była specjalnie na ten cel utworzoną linią kolejową. Do 1880 roku większość studentów mieszkała $\mathrm{w}$ akademikach $\mathrm{w}$ centrum miasta, a nie na terenie kampusu. Tylko najzdolniejsi mieli przywilej mieszkania na terenie Uczelni. Zmieniło się to $\mathrm{w}$ następnych latach, kiedy na terenie kampusu wybudowano Resident Hall, służący właśnie jako akademik dla młodzieży studenckiej. W 1893 roku Uniwersytet pogrążył się w żałobie po śmierci jego założyciela Ojca Edwarda Sorina, na którego cześć wzniesiono upamiętniający jego osobę pomnik ${ }^{12}$.

W 1902 roku za sprawą Ojca Josepha Carriera powstał Wydział Chemii i Farmacji, a następnie Szkoła Prawa i Architektury. W roku 1906 dwaj studenci Michael i John Shea skomponowali słynny hymn uczelni „Marsz Zwycięski" (ang. The Notre Dame Victory March), który to utwór do dnia dzi-

${ }^{11}$ Tamże, s. 61.

12 Tamże, s. 82. 
siejszego jest wizytówką Uniwersytetu Notre Dame ${ }^{13}$. W tym samym roku nowym rektorem został John W. Cavanaugh, za którego kadencji studiowało już ponad 800 studentów. Cavanaugh rozwinął także na Uniwersytecie dziennikarstwo i nauki społeczne ${ }^{14}$.

W czasie I wojny światowej na terenie Uniwersytetu powstały Wojskowe Jednostki Studenckie (ang. Student's Army Training Corps, SATC), szkolone przez oficerów i przechodzące specjalny kurs wojskowy. Po wojnie odnotowano ponownie gwałtowny rozwój Uniwersytetu i w 1919 roku liczył on już 1,2 tys. studentów. James Burns, który w latach 1919-1922 piastował urząd rektora, zreorganizował strukturę tej Uczelni. Sprawił też, że podniósł się znacznie standard życia studentów, jak też zwiększyły źródła jej dofinansowania. W 1920 otrzymał 5 milionów dolarów na rozbudowę kampusu, czyli 4 razy więcej niż dotychczas wydał. James Burns był pierwszym rektorem w historii Uniwersytetu Notre Dame, który miał tytuł doktora. Uniwersytet rozwijał się w każdej dziedzinie. W 1920 słynny architekt Francis Kervick stworzył teatr na świeżym powietrzu, który przyciągał miłośników sztuki. W tym okresie duży rozwój nastąpił również w dziedzinie sportu. W specjalnej hali sportowej Rockne Memorial znajdował się basen, boiska do gry w piłkę nożną, koszykówkę oraz squasha. Największy jednak rozwój przeżywał futbol za sprawą wybitnego trenera Kennetha Rockne. Ściągnął on do swojej drużyny futbolowej bardzo obiecującego zawodnika baseballu George'a Grippa, który wkrótce stał się legendą Uczelni. Rockne prowadzący ówczesną drużynę uniwersytecką Notre Dame osiągnął duże sukcesy sportowe. Zginął jednak tragicznie w wypadku lotniczym. Za pośrednictwem Rockne i Grippa futbol stał się wizytówką Uniwersytetu, a ich drużyna była sławna na całą Amerykę. Popularność drużyny futbolowej wywodzącej się z Uniwersytetu Notre Dame przetrwała po dzień dzisiejszy ${ }^{15}$.

W latach 1928-1934 rektorem Uczelni był Ojciec Charles O’Donnell. Za jego kadencji powstał pierwszy budynek - William T. Phelan Hall - sfinansowany przez prywatną osobę i nazwany imieniem jego ofiarodawcy. $\mathrm{Na}$ terenie Uniwersytetu istniał także szpital. Znaczącą rolę odgrywały w nim siostry zakonne, które oprócz opieki nad chorymi zajmowały się gastronomią. W 1932 roku utworzono University's Graduate School i od tego roku zaczęto na Uniwersytet przyjmować kobiety. Rok później powstał Samorząd Studencki (ang. Students Activities Committee - SAC) zajmujący się organi-

13 J. Heisler, 100 Things Notre Dame Fans Should Know \& Do Before They Die, Chicago Illinois 2013, s. 26.

14 A.J. Blasi, B.F. Donahoe, History of Sociological Research and Teaching at Catholic Notre Dame University, Indiana 2002, s. 32.

15 C. Grant, Before Rockne at Notre Dame, $1^{\text {st }}$ edition, New York 1968, s. 17. 
zacją życia studenckiego na terenie kampusu. W roku 1942 Uniwersytet obchodził stulecie istnienia i z tej okazji Ojciec Artur Hope wydał książkę Notre Dame, stulecie istnienia (ang. Notre Dame, One Hundred Years). Był to czas II wojny światowej, która niekorzystnie wpłynęła na rozwój Uczelni. Ojciec O’Donnell w 1941 roku utworzył program wojskowy dla studentów Naval Reserve Officers Training Corps (NROTC), który kształcił ich w różnych specjalnościach wojskowych. Lata powojenne to ponowny rozwój Uniwersytetu. W 1954 roku powstała Uniwersytecka Galeria Sztuki (ang. The University Art Galery) mieszcząca ponad 4 tysiące różnych dzieł. Ponadto, znacznie rozbudowano (aż do 59 tysięcy miejsc) stadion uniwersyteckiej drużyny futbolowej, którą nazwano „Walczącym Irlandczykiem” (ang. Fighting Irish) ze względu na dużą liczbę Irlandczyków zasiedlających te tereny. Obecnie stadion mieści ponad 80 tysięcy widzów ${ }^{16}$. Rozbudowano także salę do koszykówki do ponad 6 tysięcy miejsc. Nieustannie zwiększano również liczbę akademików i w roku 1942 było ich już około 2 tysięcy ${ }^{17}$.

W roku 1952 rektorem Uczelni został Theodore Martin Hesburgh, który urząd ten piastował najdłużej, bo aż 35 lat. Jego celem było stworzenie, jak sam podkreślał, „nowego Notre Dame” (ang. new Notre Dame). Dokonał reformy Uniwersytetu, tworząc nowoczesną uczelnię, zachowując jej katolicki charakter. Budżet Uniwersytetu zwiększył się o około 80 mln dolarów. Postawały nowe budynki, miedzy innymi słynna biblioteka The Memorial Library, wybudowana w 1964 roku, na której murach widniał wizerunek Jezusa otoczonego przez apostołów. Budynek ten stoi do dziś i robi duże wrażenie na turystach zwiedzających Uniwersytet. Powstawały także obiekty sportowe, między innymi hala sportowa Athletic and Convocation Center wybudowana w 1968 roku, w której swoje mecze rozgrywała i rozgrywa do dziś uniwersytecka drużyna. Lata osiemdziesiąte i dziewięćdziesiąte XX wieku, to ciągły rozwój Uczelni zarówno pod względem strukturalnym, jak i kadrowym; powstawały kolejne nowe budynki oraz zwiększała się liczba pracowników i studentów ${ }^{18}$.

W 2005 roku rektorem Uczelni został John I. Jenkins, pełniący tę funkcję do dzisiaj. Obecnie uniwersytet zajmuje teren o powierzchni 1250 akrów, na którym stoi blisko 140 budynków o łącznej wartości 2,2 mld dolarów, z bazyliką Secred Hart, czternastopiętrową biblioteką Hesburgha (ang. The Hesburg Library), 126-letnim Starym Budynkiem Głównym (ang. The Old Main Building), ze słynną Złotą Kopułą (ang. Golden Dome). Co roku powstają

16 J. Heisler, 100 Things Notre Dame Fans Should Know, s. 7.

17 W. Francis, Notre Dame: It's People It's Legends, New York 1969, s. 34.

18 T.J. Schlereth, The University of Notre Dame, s. 205. 
nowe budynki, jak na przykład: Centrum Sztuki Debartolo (ang. The Debartolo Art. Center), The Guglielmino Complex, The Jordan Hall of Science, Stinson Remick Hall. Budżet Uniwersytetu z roku na rok dynamicznie wzrastał i od 1920 do 1952 roku, kiedy rektorem był Ojciec Hesburgh, wzrósł o 7 mln dolarów, ale już w roku 1980 sięgał 150 mln dolarów. Obecnie wynosi 6,5 mld dolarów i Notre Dame jest 15. uniwersytetem w kraju pod względem posiadanych środków finansowych. Uczelnię pod nadzorem rektora prowadzą dwie grupy: urzędnicy uniwersyteccy (ang. Fellows of the University) oraz istniejąca już za czasów Ojca Sorina Rada Nadzorcza (ang. Board of Trustees). Są one odpowiedzialne za tworzenie statutu Uczelni. Sprawami akademickimi zajmuje się wicerektor (provost). Obecnie jest nim dr Thomas Burish. Uniwersytet składa się z 4 dydaktycznych college'ów Sztuki i Literatury (ang. Arts and Letters), Nauki (ang. Science), Politechniki (ang. Engineering) i College'u Biznesu Mendoza (ang. Mendoga College of Business). Poza tym istnieje Szkoła Architektury (ang. The School of Architecture), Szkoła Prawa (ang. The Law School) oraz Studium Doktoranckie (ang. The Graduate School), które kształci przyszłych magistrów i doktorów. Oferuje im ono ponad 40 programów studiów magisterskich, jak też ponad 20 doktorskich.

Uniwersytet posiada również 10 głównych naukowych instytucji, więcej niż 40 centrów i specjalnych programów oraz bardzo rozwinięty system biblioteczny. Badania naukowe prowadzone są $\mathrm{w}$ wielu dziedzinach, między innymi biochemii, mechaniki płynów, fizyki, biologii, marketingu itp. Obecnie na Uniwersytecie Notre Dame studiuje ponad 12 tysięcy studentów, w tym 3 tysiące magistrów i doktorów. Duża ich część (ok. 70\%) zaangażowana jest $\mathrm{w}$ wolontariat dla społeczności akademickiej. Istnieje specjalne Centrum Pomocy Społecznej (ang. Center of Social Concerns). Około 37\% studentów Notre Dame pochodzi ze środkowozachodnich stanów, a znaczną grupę stanowią tam studenci z ponad 100 krajów. Kształci ich 1241 profesorów pełnoetatowych i 166 profesorów zatrudnionych na pół etatu, czyli średnio na jednego profesora przypada trzynastu studentów ${ }^{19}$.

Za wychowanie fizyczne na Uniwersytecie Notre Dame odpowiedzialny jest Wydział Wychowania Fizycznego (ang. Departament of Physical Education), który realizuje swój program opierając się na czterech głównych koncepcjach:

1. Edukowanie młodzieży akademickiej w zakresie:

a) zdrowia,

19 Notre Dame University, dane ogólne o uniwersytecie, adres internetowy: https://www.nd.edu/about/at-a-glance/students/ 
b) sprawności fizycznej,

c) wartości codziennej aktywności fizycznej.

2. Promocja pozytywnych aspektów zdrowego trybu życia wpływającego na codzienne życie młodzieży akademickiej teraz i w przyszłości.

3. Pomoc studentom $\mathrm{w}$ rozwijaniu zainteresowań związanych z wychowaniem fizycznym i rekreacją.

4. Stworzenie odpowiednich warunków umożliwiających rozwój „umysłu, ducha i ciała" 20 .

Cele, jakie stawia sobie Wydział Wychowania Fizycznego na Uniwersytecie Notre Dame to:

1) oferowanie zróżnicowanego, atrakcyjnego programu zajęć z wychowania fizycznego dostosowanego do potrzeb i zainteresowań młodzieży akademickiej;

2) oferowanie rozległego zakresu zajęć z wychowania fizycznego, ze szczególnym uwzględnieniem zajęć dla początkujących i średnio zaawansowanych;

3) wpojenie studentom pozytywnej roli oraz korzyści płynących z regularnych ćwiczeń i aktywności fizycznej;

4) zachęcanie studentów do zdrowego trybu życia opartego na odpowiednich ćwiczeniach fizycznych i zdrowym jedzeniu;

5) promowanie koncepcji rozwoju „umysłu, ciała i ducha” 21.

Strukturę organizacyjną sportu na Uniwersytecie Notre Dame przedstawia rycina 1.

Wydział Wychowania Fizycznego jest kierowany i reprezentowany przez Kierownika. Podlega mu jego Zastępca Asystent oraz 14 pozostałych pracowników, którzy szkolą $\mathrm{w}$ zakresie wychowania fizycznego około 2 tysięcy studentów pierwszego roku. Istnieje jeszcze Wydział Sportu (ang. Department of Athletics), który specjalizuje się w szkoleniu sekcji uniwersyteckich poprzez zatrudnianie wysoko wykwalifikowanych trenerów.

Wychowanie fizyczne na Uniwersytecie Notre Dame jest obowiązkowe przez pierwszy rok studiów i trwa dwa semestry. Następnie staje się ono nieobowiązkowe. Studenci wybierają i uczęszczają na zajęcia sekcji zajmujących się interesującą ich dyscypliną sportu. Daną dyscyplinę sportu, na którą zamierzają uczęszczać wybierają na pierwszym roku studiów. Wyboru tego dokonują $\mathrm{w}$ specjalnym budynku przeznaczonym dla pierwszorocznia-

${ }^{20}$ M. Schmidt, Contemporary Topics for College Students: A Resource Guide to Wellness, Third Edition, Notre Dame, Indiana 2009, s. 15.

${ }^{21}$ M. Schmidt, The Promotion of the Department of Physical Education and Wellness Instruction on Campus, Notre Dame, Indiana May 2009, s. 5. 


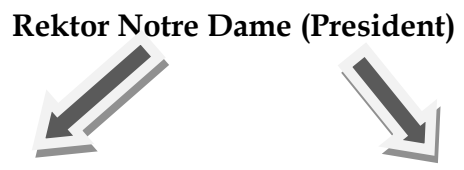

Kierownik

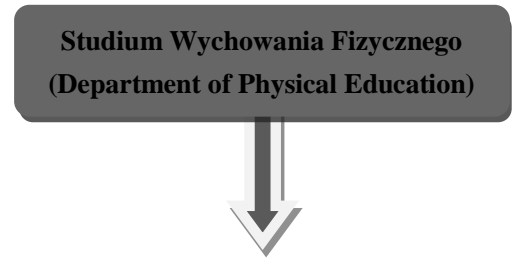

Dydaktyka - wychowanie fizyczne (nauczyciele wych. fiz.)

Dyrektor

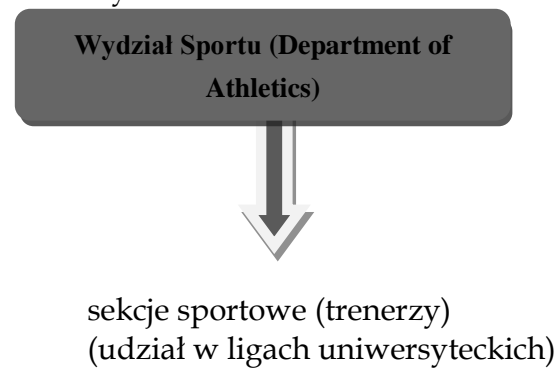

Ryc. 1. Struktura organizacyjna sportu na Uniwersytecie Notre Dame w USA (opracowanie własne)

ków - Coleman-Morse. W początkowej fazie są to tak zwane zajęcia selekcyjne, na których nauczyciele wychowania fizycznego tworzą grupy. Co ciekawe, student potrafiący grać na przykład w koszykówkę, nie może wybrać tej dyscypliny sportu jako przedmiotu wychowania fizycznego. Musi wybrać taką dyscyplinę, której jeszcze nie uprawiał i spotkania "selekcyjne” mają właśnie na celu wyeliminowanie takiej sytuacji. Zatem, celem Wydziału Wychowania Fizycznego (ang. Department of Physical Education) jest nauczanie studentów nowych dyscyplin sportowych. Natomiast, jeśli student chce doskonalić ulubioną przez niego dyscyplinę sportową, wybiera dodatkowo specjalne sekcje, które podzielone są na odpowiednie poziomy średnio zaawansowany oraz zaawansowany. $W$ drugim semestrze studenci mogą już zapisywać się na wychowanie fizyczne poprzez Internet, w swoich pokojach na kampusie, co znacznie ułatwia ich ewidencję. $W$ zajęciach $\mathrm{z}$ wychowania fizycznego uczestniczą dwa razy w tygodniu. Pod koniec roku, czyli po 2 semestrach nie ma egzaminu końcowego. Nauczyciel wystawia jedynie symbol "S" (ang. Satisfactory), czyli "satysfakcjonujący” lub „U” (ang. Unsatisfactory), czyli „niesatysfakcjonujący”, co jest uzależnione od:

- zaangażowania studenta w zajęciach,

- obecności na zajęciach,

- aktywności i dyscypliny,

- zachowania 22.

22 Tamże, s. 15. 
Podstawą do zaliczenia przedmiotu z wychowania fizycznego jest zaliczenie testu z pływania. Ten test jest obowiązkowy dla każdego studenta, ponieważ jak głosi polityka uczelni: „każdy student powinien umieć poradzić sobie w wodzie". Składa się on z dwóch jednostek:

1. Pływanie podstawowe - nauka utrzymania się na wodzie, zachowań z tym związanych, oddechu oraz nauka stylu kraula na grzbiecie i na piersi.

2. Pływanie zaawansowane - doskonalenie poznanych stylów oraz nauka stylu klasycznego i motylkowego 23 .

Zaliczenie polega na zdaniu testu teoretycznego z pływania i zasad bezpieczeństwa w wodzie oraz testu praktycznego - przepłynięciu 300 jardów z wykorzystaniem stylu kraula na grzbiecie, na piersiach oraz stylu klasycznego ${ }^{24}$. Wychowanie fizyczne jest obowiązkowe, ale gdy student nie uczestniczy w zajęciach, otrzymuje wówczas notę „ $\mathrm{U}^{\prime \prime}$ i jest zobowiązany do powtórzenia danego przedmiotu. Jednakże, nie jest zmuszany do uczestnictwa w tych zajęciach, co stanowi celowe działanie władz Uczelni, żeby nie zmuszać „siłą” do zajęć, lecz zachęcać poprzez rozległy wachlarz programu wychowania fizycznego oraz fachowość kadry na Wydziale Wychowania Fizycznego. Poza tym, Uczelnia ma wówczas obraz, jaki procent studentów uczęszcza na zajęcia z wychowania fizycznego bez przymusu i okazuje się że jest to zdecydowana większość. Nauczyciele mają jednak prawo nie wpuścić na zajęcia studentów, którzy z niewyjaśnionych powodów opuszczą więcej niż 3 zajęcia $w$ ciągu semestru oraz regularnie spóźniających się. Co więcej, mogą też $\mathrm{w}$ ogóle skreślić ich z listy studentów uczestniczących $\mathrm{w}$ zajęciach $\mathrm{z}$ wychowania fizycznego. Tym samym, student taki zamyka sobie drogę do uczestnictwa w tych zajęciach przez cały rok. W rzeczywistości jednak sytuacje takie należą do rzadkości i studenci z chęcią biorą udział $\mathrm{w}$ tych zajęciach. Należy jednak zwrócić uwagę, że zasady dyscypliny są bardzo szczegółowo określone i ściśle przestrzegane przez pracowników Uczelni na każdym wydziale ${ }^{25}$. Oprócz tego wychowanie fizyczne na Uniwersytecie Notre Dame składa się z dwóch tak zwanych "torów":

- pierwszy "Wellness track” („tor zdrowotnościowy”), czyli zajęcia wpływające zdrowotnie na organizm, czyli pływanie, fitness, rozciąganie, wodny aerobik, joga, ratownictwo (udzielanie pierwszej pomocy);

${ }^{23}$ Tamże, s. 19.

${ }^{24}$ M. Schmidt; Contemporary Topics for College Students, s. 22.

${ }^{25}$ Dane uzyskane przez autora $z$ dokumentów znajdujacych się w Departamencie Wychowania Fizycznego na Uniwersytecie Notre Dame, Indiana oraz $z$ wywiadów przeprowadzonych $z$ nauczycielami wychowania fizycznego na tym uniwersytecie. 
- drugi "Activities track” („tor aktywności sportowej”), czyli zajęcia z takich typowych sportów, jak: golf, tenis, piłka nożna piłka ręczna, koszykówka, amerykański football, siatkówka itp.

Studenci są zobowiązani do uczestniczenia $\mathrm{w}$ zajęciach $\mathrm{z}$ obydwu tych "torów”. Większość zajęć z wychowania fizycznego jest oferowana dla poziomu początkującego (ang. Beginning Level). Oferta zajęć z wychowania fizycznego na Uniwersytecie Notre Dame to: taniec, kulturystyka, joga, pływanie, bowling, zajęcia teoretyczne (higiena, dietetyka, suplementacja), kolarstwo, szermierka, samoobrona, golf, piłka ręczna, rocketball, łyżwiarstwo, skauting, jogging, nurkowanie, narciarstwo, piłka nożna, tenis, frisbee, siatkówka, podnoszenie ciężarów, zajęcia "Contemporart topice" (są to zajęcia, które mają pomóc młodzieży przygotować się na to "przejście” ze szkoły średniej na uczelnię wyższą, pomóc im przystosować się i zaaklimatyzować w nowym, bardziej dorosłym już środowisku) ${ }^{26}$. Wydział Wychowania Fizycznego kładzie duży nacisk na realizację koncepcji rozwoju „umysłu, ciała i ducha". Nauczyciele tego wydziału uważają, że wzajemne oddziaływanie umysłu, ciała i ducha powoduje większe zrozumienie potrzeby i korzyści płynących z aktywności fizycznej, sprawia, że stajemy się sprawniejsi, zdrowsi i bardziej usatysfakcjonowani z życia. Taką ideę wychowania fizycznego pragną zaszczepić wśród młodzieży akademickiej na swojej uczelni. Podczas zajęć panuje przyjazna atmosfera, a brak przymusu do zajęć powoduje, że młodzież akademicka jeśli już uczęszcza na dane zajęcia z wychowania fizycznego, to chce wykorzystać ten czas do maksimum i pozyskać jak najwięcej informacji. Zdobytą wiedzę mogą powielać podczas samodzielnych ćwiczeń pozalekcyjnych.

Jeśli chodzi o typowe sekcje sportowe reprezentujące Uczelnię w zawodach międzyuczelnianych, to zajmuje się nimi nie Wydział Wychowania Fizycznego, a specjalna osobna jednostka - Wydział Athletics. Zatrudnieni są tam osobni trenerzy prowadzący sekcje sportowe. Obydwie jednostki, czyli Wydział Wychowania Fizycznego i Wydział Athletics, nic nie łączy; mają osobne kierownictwo oraz pracowników. Każdy student "sportowiec” jest również zobowiązany do przestrzegania regulaminu, wszystkich zasad i wytycznych uniwersyteckich oraz zdobywania wiedzy i zdawania egzaminów. Każdy ma specjalny podręcznik dla Wydziału Athletics, w którym poruszana jest tematyka związana z suplementacją, regeneracją, odżywianiem, treningiem oraz $\mathrm{z}$ problemem alkoholowym czy narkotykowym ${ }^{27}$.

${ }^{26}$ M. Schmidt, The Promotion of The Department of Physical Education, s. 15-20.

27 University of Notre Dame, przewodnik studentów Wydziału Athletics, Student - Athlete Handbook, s. 1-3. 
Sekcje sportowe na Wydziale Athletics to zaplecze lig i profesjonalnych klubów. Wielu młodych zawodników z drużyny akademickiej przechodzi na zawodowy sport podpisując wielomilionowe kontrakty. Budżet na sport na Uniwersytecie Notre Dame to około 50 mln dolarów, co świadczy, jak ważną rolę odgrywa on na tej Uczelni. Każda sekcja sportowa ma ogromną bazę treningową oraz własny obiekt treningowy. Na przykład, drużyna futbolowa ma osobny budynek, gdzie znajduje się siłownia ze specjalistycznym sprzętem i tylko zawodnicy oraz sztab szkoleniowy mogą z niej korzystać. Student niebędący członkiem drużyny nie może tam nawet wejść. Należy również wspomnieć, że Uniwersytet Notre Dame dużą ilość środków przeznaczonych na sport zdobywa od prywatnych darczyńców, tak zwanych "Alumni" - sponsorów przekazujących niejednokrotnie wysokie sumy na daną dyscyplinę sportową. Na budowę nowych obiektów sportowych Uczelnia otrzymuje niejednokrotnie dotacje z ministerstwa lub dotacje unijne. Wydział Athletics prowadzi następujące sekcje sportowe: żeńskie - koszykówka, szermierka, golf, lacrosse, piłka nożna, softball, pływanie, skoki do wody, tenis, lekkoatletyka, siatkówka, wioślarstwo; męskie - baseball, koszykówka, szermierka, golf, hokej, lacrosse, piłka nożna, tenis, lekkoatletyka oraz najbardziej popularna dyscyplina futbol amerykański. Drużyna futbolu amerykańskiego Notre Dame Fighting Iris (Notre Dame walczący Irlandczyk) jest wizytówką Uczelni. Bierze ona udział w prestiżowych rozgrywkach krajowych uniwersyteckiego footballu amerykańskiego, organizowanych przez National Collegiate Athletic Association. Można uznać, że jest to zaplecze do zawodowej ligi NFL i zawodnicy z drużyn uniwersyteckich podpisują wielomilionowe kontrakty w zawodowej lidze futbolu amerykańskiego. Podobnie zresztą jest z innymi sportami: koszykówką, baseballem czy hokejem ${ }^{28}$. Na Uniwersytecie Notre Dame największe sukcesy zdobyła drużyna futbolu amerykańskiego - 11 razy mistrzostwo NCAA (1924, 1929, 1930, 1943, 1946, 1947, 1949, 1966, 1973, 1977 i ostatnie w 1988 roku). Poza tym, siedmiu zawodników drużyny zdobyło najbardziej prestiżową nagrodę indywidualną Heisman Trophy, przyznawaną co roku najlepszym akademickim graczom futbolowym. Również dziesięciu najbardziej zasłużonych byłych zawodników Fighting Irish zostało przyjętych do Pro Football Hall of Fame. Obecnie drużyna futbolowa zajmuje regularnie miejsca w pierwszej 15. najlepszych zespołów. Według College Football Rankings, Notre Dame Fighting Irish zajęło w 2015 roku 11. miejsce. Oprócz

${ }^{28}$ Dane uzyskane przez autora z dokumentów znajdujących się w Departamencie Wychowania Fizycznego na Uniwersytecie Notre Dame, Indiana oraz z wywiadów przeprowadzonych z nauczycielami wychowania fizycznego na tym uniwersytecie. 
drużyny futbolu amerykańskiego, na bardzo wysokim poziomie stoi piłka nożna kobiet; dwukrotnie zdobyto $\mathrm{w}$ tej dyscyplinie mistrzostwo kraju (w 1995 i 2004 roku). Również koszykówka kobiet może poszczycić się tytułem mistrzowskim z 2001 roku. Koszykówka mężczyzn plasuje się regularnie w pierwszej 15. najlepszych uniwersyteckich zespołów koszykarskich w Stanach Zjednoczonych. Bardzo udanym sezonem był sezon 2014-2015, w którym zajęła 4 . miejsce w NCAA ${ }^{29}$. Na bardzo wysokim poziomie stoi również tenis żeński, a szermierka plasuje się w czołówce zespołów akademickich w całym kraju. Uniwersytet Notre Dame corocznie zajmuje wysokie miejsca w wynikach sportowych. Jak już wspomniano, sport na uczelniach amerykańskich, również i na tej Uczelni, traktowany jest bardzo poważnie, $\mathrm{w}$ pełni profesjonalnie, a co za tym idzie - motywowane jest to przez odpowiednie, bardzo wysokie jak na warunki uniwersyteckie środki finansowe. Tutaj jednak nikogo to nie dziwi, gdyż sport uniwersytecki w Stanach Zjednoczonych jest bardzo bliski zawodowemu. Jak już wspomniano, wielu zawodników (w większości taki jest ich cel i marzenie) poprzez rozgrywki uniwersyteckie ma możliwość wybicia się i przejścia w następnej fazie na zawodowstwo i tu przykładów jest bardzo dużo.

Znaczącą rolę w zdobywaniu wysokich miejsc na uniwersyteckiej arenie sportowej odgrywa oczywiście baza sportowa. Na terenie kampusu znajdują się dwie 15-tysięczne hale sportowe do gier zespołowych, koszykówki, hokeja na lodzie. Poza tym, na terenie kampusu znajduje się około 20 kortów tenisowych odkrytych, na których treningi mają różnego rodzaju szkółki tenisowe oraz rozgrywanie są mistrzostwa uniwersyteckie, 6 kortów tenisowych krytych. Poza tym, tak zwany Sport Center (gdzie są 4 boiska do koszykówki, 2 boiska do halowej piłki nożnej, boiska do siatkówki, siłownia z różnego rodzaju sprzętem fitness oraz z przyrządami ciężko atletycznymi, gdzie trenują kulturyści i zawodnicy sekcji trójboju siłowego, a na samej górze dookoła sali znajduje się specjalna bieżnia lekkoatletyczna). Posiadają również 2 baseny 25-metrowe, 15 boisk do koszykówki - wszystkie wyposażone w oświetlenie (jako że studenci grają w koszykówkę przy bardzo upalnym lecie również w nocy), pełnowymiarowe boiska do piłki nożnej, boiska treningowe do footballu amerykańskiego oraz stadion z 80-tysięczną widownią do footballu amerykańskiego, na którym rozgrywa swoje mecze główna drużyna ${ }^{30}$.

${ }^{29}$ Najlepsze osiągnięcia sportowe Uniwersytetu Notre Dame, adres strony internetowej: http://espn.go.com/menscollegebasketball/rankings/_/poll/2/year/2015/week/4/seasont ype/3

${ }^{30}$ Notre Dame Sport Facilities, obiekty sportowe Notre Dame University, adres strony internetowej: http://www.und.com/facilities/nd-facilities.html. 
W latach 2012-2014 przeprowadziłem podczas kolejnych pobytów studyjnych na Uniwersytecie Notre Dame badania jakościowe dotyczące funkcjonowania tam systemu fizycznego ( $w$ celach porównawczych podobne badania przeprowadziłem na UAM). Główny problem badawczy przyjął następującą postać: jak amerykańscy nauczyciele wychowania fizycznego na poziomie uniwersyteckim postrzegają rolę prowadzonych przez siebie zajęć w urzeczywistnianiu potencjału rozwojowego studentów? Chciałem zrozumieć, w jaki sposób nauczyciele subiektywnie postrzegają różnorodne aspekty funkcjonowania wychowania fizycznego na amerykańskiej uczelni wyższej. W wywiadach przeprowadzonych na Uniwersytecie Notre Dame, w South Bend, Indiana, wzięło udział 8 osób (jedna kobieta i siedmiu mężczyzn). Wszyscy byli nauczycielami wychowania fizycznego ze stażem pracy od 6 do 15 lat. Poniżej przedstawię wybrane fragmenty z badań jakościowych, odnoszące się jedynie do satysfakcji zawodowej nauczycieli wychowania fizycznego na Uniwersytecie Notre Dame (wypowiedzi amerykańskich nauczycieli wychowania fizycznego zostały oznaczone jako symbole A1-A7).

Z całą pewnością można stwierdzić, że satysfakcja zawodowa stanowi jak gdyby przeciwny biegun wypalenia zawodowego. Zawód nauczyciela wychowania fizycznego nie jest szczególnie prestiżowy, ani nie jest źródłem wysokich dochodów - ani w Polsce, ani w Stanach Zjednoczonych, ani w większości krajów świata. Do pewnego stopnia zaskoczył mnie więc fakt, że większość amerykańskich nauczycieli wychowania fizycznego biorących udział w wywiadach nie tylko nie czuje się wypalona, lecz wręcz przeciwnie - z dużą radością podejmuje swoje obowiązki oraz czerpie ze swojej pracy dużą satysfakcję. Można dostrzec kilka kontekstów tego zagadnienia. Nauczyciele odpowiadają, że cieszy ich dobry kontakt z młodymi ludźmi, który sprawia, że sami czują się młodo. Codzienna praca z młodzieżą mobilizuje nauczycieli do dbania także o własną sprawność fizyczną. Trzeba zwrócić uwagę, że specyfika pracy nauczyciela wychowania fizycznego jest odmienna od codzienności nauczyciela matematyki, historii, czy języka. Wychodzi on poza klasę szkolną, nie jest zamknięty w sali wykładowej, lecz wychodzi w przestrzeń, a jego kontakt ze studentami, uczniami może być bardziej nieformalny i mniej opierać się na szkolnych czy akademickich konwencjach, typowych dla lekcji matematyki, gdzie istnieje podział nauczyciel uczniowie.

Metoda klasycznego wykładu, czy sprawdzania wiedzy za pomocą testów na zajęciach $\mathrm{z}$ wychowania fizycznego zmienia się bardzo często we wspólnotę wysiłku dążenia do pewnej perfekcji. Nauczyciel wychowania 
fizycznego staje się jednym z nich. Nie ma ostrych podziałów, a dyscyplinie która jest nieodłączna w uprawianiu sportu i ćwiczeniom fizycznym towarzyszy dużo radości. Co więcej, nawet zmęczenie może przynosić satysfakcje. Powyższe tezy znakomicie są zilustrowane przez dwie wypowiedzi amerykańskich nauczycieli wychowania fizycznego.

A5: Moja praca pozwala mi być samemu $w$ dobrej formie, bo często trenuje razem ze studentami, pokazuje im jak prawidtowo wykonywać dane ćwiczenie, co powoduje, że ja także ciągle się rozwijam, utrzymuję dobrą kondycję i sprawność.

A6: Kontakt z młodzieża ma również wptyw na moją osobę, gdyź ćwicząc z nimi caty czas czuje się $w$ dobrej formie, czuje się młoda i niewatpliwie jest to duży pozytywny aspekt naszej pracy.

Powodem do satysfakcji lub wręcz dumy są dla nauczycieli osiągnięcia sportowe ich wychowanków. Należy dodać, że w ramach zajęć wychowania fizycznego studenci Notre Dame są zachęcani do uprawiania tych dyscyplin sportowych oraz form aktywności fizycznej, z którymi dotąd się nie zetknęli, albo w których nie czuli się pewnie. Młody człowiek, który w szkole średniej uprawiał na przykład koszykówkę jest zobowiązany podjąć inny typ zajęć sportowych. Dzięki temu studenci zyskują nowe doświadczenia i szansę na wszechstronny rozwój. Podejmowanie przez studentów nowych wyzwań i zdobywanie umiejętności w nowych dziedzinach to także jeden z powodów odczuwania satysfakcji zawodowej przez nauczycieli wychowania fizycznego. Nie muszą to być spektakularne wyczyny, czasem sukcesem jest pokonanie własnych ograniczeń. Warto w tym miejscu przytoczyć kolejne wypowiedzi:

A4: Odczuwam satysfakcje, kiedy udaje mi się nauczyć ptywać studentów, którzy dotąd bali sie wody. Cieszy mnie obserwowanie ich postępów, to że czują się w wodzie swobodnie i bezpiecznie.

A2: Największa radość sprawiaja mi reakcje studentów w chwilach, gdy udaje im się odnieść nieoczekiwany sukces. Wielu studentów Notre Dame dąży do tego, żeby być doskonatymi we wszystkim co robia i także na zajęciach wychowania fizycznego chętnie próbuja nowych rzeczy. Kiedy zdobęda umiejętności, pozwalające na osiagnięcie sukcesu, napawa mnie to duma i dodaje mi wiary w to, co robię.

Prawdziwą satysfakcję daje amerykańskim nauczycielom możliwość wpływania na rozwój młodych ludzi, nie tylko w dziedzinie wychowania 
fizycznego. Jeden uczestnik wywiadów podkreśla, że podczas zajęć wychowania fizycznego często ujawnia się osobowość młodego człowieka, ale także problemy psychologiczne, z którymi student się zmaga. Doświadczony nauczyciel wychowania fizycznego jest w stanie pomóc zdiagnozować problem i wskazać sposób jego rozwiązania. To są najbardziej satysfakcjonujące momenty $\mathrm{w}$ pracy pedagogicznej. $\mathrm{W}$ takie podejście wpisuje się poniższa wypowiedź.

A1: Miatem kiedyś przypadek futbolisty, który nie radzit sobie na studiach, nie byt w stanie skoncentrować się na nauce, nie zdawat egzaminów, często nawet do nich nie podchodził. Udało mi sie przekonać go do dodatkowych, indywidualnych zajęć i po niemal roku naszej wspólnej walki przyszedt mi podziękować. Do dziś mamy dobry kontakt.

Powyższy przykład skłania do kolejnej refleksji, bowiem wskazuje, że uczestnictwo w zajęciach wychowania fizycznego i sportu może przyczynić się do rozwiązania problemów życiowych czy psychicznych, które spotykają człowieka w jego życiu. To zresztą wpisuje się w zdroworozsądkowe przekonanie, że ćwiczenia fizyczne stanowią skuteczny oręż w walce $\mathrm{z}$ obniżeniami nastroju, „czyszczą umysł i ducha z niepokojów”, wpływają pozytywnie na stres, sprawiają, że życie i rzeczywistość postrzegane są w bardziej pozytywny sposób. Praca ze studentami dopinguje nauczycieli do nieustannego zawodowego rozwoju, co także stanowi źródło satysfakcji i potwierdzenia własnej roli zawodowej. Można stwierdzić, że praca nauczyciela wychowania fizycznego nie ma charakteru statycznego, lecz dynamiczny, a rozwijanie swoich wszechstronnych kompetencji potwierdza poczucie własnej wartości i poczucie misji zawodowej. Warto podać choć jeden przykład takiej interpretacji.

A5: Największa satysfakcję czuję, kiedy studenci podchodza do mnie z pytaniami np. "jak się odżywiać, jak rozłożyć trening na poszczególnych etapach, z jakimi ciężarami zaczać, ile jednostek treningowych zaplanować w tygodniu itp." Dlatego też siegam do nowych metod treningowych, biorę udziat w różnych kursach $i$ konferencjach sportowych, żeby wiedza, która przekazuje studentom byta jak najbardziej aktualna.

Potwierdzeniem wartości wykonywanej przez nauczycieli pracy i nagrodą za ich zaangażowanie jest fakt, że studenci chcą uczestniczyć w zajęciach nadobowiązkowych. 
A1: Jestem bardzo zadowolony, kiedy student po zakończeniu obowiazkowego kursu zajęć z wychowania fizycznego zgłasza się do mnie, żeby nadal uczestniczyć w ćwiczeniach. Takich przypadków jest całkiem sporo.

Podsumowując, należy powtórzyć, że wywiady wykazały wysoki poziom satysfakcji zawodowej nauczycieli wychowania fizycznego z Uniwersytetu Notre Dame. Może to dziwić w świetle nienadzwyczajnych zarobków i prestiżu. Ze zdobytej wiedzy wynika jednoznacznie, że zawód ten uprawiają osoby, które znajdują w swoich działaniach satysfakcję niezależną od gratyfikacji finansowych i miejsca swojego zawodu na drabinie prestiżu.

Z powyższych analiz i interpretacji wyłania się nieoczekiwanie obraz nauczyciela wychowania fizycznego jako profesji niemal idealnej, w której dominuje satysfakcja i przekonanie o dobrze wybranej drodze zawodowej. W związku z tym próbowałem uzyskać również odpowiedzi na pytania odnośnie negatywnych stron tego zawodu. Nie uzyskałem na ten temat szczególnie głębokiej wiedzy, ale warto przeanalizować dwa konteksty tego zagadnienia. Większość nauczycieli uskarża się na zbyt niskie wynagrodzenia, choć każdy z nich deklaruje, że pieniądze nie są jedynym motywem dla zaangażowania się $\mathrm{w}$ pracę na uczelni. Warto też zwrócić uwagę, że niemal wszyscy respondenci uważają, że edukacyjna wartość ich pracy, a także ich rola jako wychowawców mających wpływ na rozwój osobowości młodego człowieka nie jest dostatecznie doceniana w środowisku akademickim. Przytoczę $w$ tym miejscu trzy najbardziej charakterystyczne wypowiedzi:

A7: Wychowanie fizyczne jest mało doceniane przez ogót, niektórzy nie zdaja sobie sprawy jaka istotna role ogrywa w życiu każdego $z$ nas ruch $i$ aktywność fizyczna.

A3: Niektórzy wykładowcy innych przedmiotów nie traktuja wychowania fizycznego jako istotnego sktadnika wyższego wykształcenia.

A5: Niektórzy nie zdają sobie sprawy, jak ważna rolę odgrywa wychowanie fizyczne $i$ aktywność fizyczna w rozwoju młodego człowieka. Jeśli w wieku 20 lat człowiek nie dostrzega zdrowotnej roli aktywności ruchowej, a pod wptywem naszych zajęć zmienia swoja postawę, to jest bardzo ważna zmiana, mająca wptyw na dalsze jego życie. Poza tym nasza praca ma jeszcze ważny, a niedoceniany aspekt wychowawczy. Mamy kontakt z różnymi osobowościami, niektórzy studenci wspótpracuja bez zarzutu, inni jednak sprawiaja poważne problemy, z którymi my jako wychowawcy musimy umieć sobie radzić. 
Komentując te wypowiedzi, można stwierdzić, że wpisują się one $\mathrm{w}$ pewne stereotypowe postrzeganie zawodu nauczyciela wychowania fizycznego jako "niższego" czy "gorszego" i mniej akademickiego niż przedmioty stricte kierunkowe. Nasuwa się pytanie: czy rzeczywiście jest to przedmiot dodatkowy czy może w niektórych przypadkach jest wręcz przeciwnie, bowiem może być on najbardziej ulubionym, dającym najwięcej satysfakcji, niekiedy wręcz o terapeutycznym charakterze. W oczywisty sposób rangę tego przedmiotu obniża fakt, że nie dostarcza on bezpośrednich kompetencji i kwalifikacji, które stanowią integralną część tak zwanej sylwetki absolwenta, jak na przykład takie kierunki studiów, jak historia, fizyka, czy malarstwo i rzeźba. $\mathrm{Z}$ drugiej strony mam przekonanie, że podział między tym co podstawowe a tym co dodatkowe nie powinien być tak bardzo ostro określany, tym bardziej że niekiedy przedmioty dodatkowe mogą w sposób wyraźny wspierać rozwój społeczno-zawodowy studenta.

W ostatecznej konkluzji odnoszącej się do prezentacji badań przeprowadzanych wśród nauczycieli amerykańskich pragnę jeszcze raz stwierdzić, że są to osoby zaangażowane, pozytywne, czerpiące dużą satysfakcję ze swojej pracy zawodowej na Uniwersytecie Notre Dame. W powyższym tekście przedstawiłem ogólny obraz wychowania fizycznego na tymże Uniwersytecie oraz wybrany kontekst badań jakościowych przeprowadzonych przeze mnie wśród nauczycieli wychowania fizycznego. Wydaje mi się, że ważna byłaby dalsza eksploracja tego problemu, szczególnie w kontekście porównawczym z uniwersytetami polskimi.

\section{BIBLIOGRAFIA}

Academic Ranking of World Universities, adres internetowy: http://www.shanghai ranking.com/ARWU2016.html

Blasi A.J., Donahoe B.F. , History of Sociological Research and Teaching at Catholic Notre Dame University, Edwin Mellen Press, Indiana 2002.

Cavanaugh J.W., Notes on Early History of Notre Dame, University of Notre Dame Press, South Bend Indiana 1954.

Francis W., Notre Dame: It's People It's Legends, D. McKay Co, New York 1969.

Grant C., Before Rockne at Notre Dame, 1' ${ }^{\text {st }}$ edition, Dujarier Press, New York 1968.

Heisler J., 100 Things Notre Dame Fans Should Know \& Do Before They Die, Triumph Books, Chicago Illinois 2013.

Notre Dame Sport Facilities, obiekty sportowe Notre Dame University, adres strony internetowej: http://www.und.com/facilities/nd-facilities.html.

Notre Dame University, dane ogólne o uniwersytecie, adres internetowy: https://www. nd.edu/about/at-a-glance/students/ 
QS World University Rankings, adres internetowy: https://www.topuniversities. com/university-rankings/world-university-rankings/2016.

Schlereth T.J., The University of Notre Dame. A Portrait of Its History and Campus, University of Notre Dame Press, South Bend Indiana 1977.

Schmidt M., Contemporary Topics for College Students: A Resource Guide to Wellness, Third Edition, Custom Publishing, Notre Dame, Indiana 2009

Schmidt M., The Promotion of the Department of Physical Education and Wellness Instruction on Campus, Notre Dame, Indiana May 2009.

Sperber M.A., Shake Down the Thunder, The Creation of Notre Dame Football, Indiana University Press, South Bend Indiana, 1993.

University of Notre Dame, przewodnik studentów Wydziału Athletics, Student - Athlete Handbook.

US News and World Report, adres internetowy: https://www.usnews.com/bestcolleges/rankings/national-universities.

Wack J.T., The Story of Notre Dame. The University of Notre Dame du Lac, Foundations, 18421857, Notre Dame South Bend Indiana, adres internetowy: http://archives. nd.edu/wack/wack01.htm.

World University Rankings, adres internetowy: https://www.timeshighereducation. com/world-university-rankings/2017/world-ranking\#!/page/0/length/ 25/sort_by/rank/sort_order/asc/cols/stats. 